
аспірантка кафедри економічної теорії та конкурентної похітики Київський національний торговельно-економічний університет

\title{
НАПРЯМИ ЗАБЕЗПЕЧЕННЯ СТІЙКОСТІ ЕКОНОМІКИ В УМОВАХ ГЛОБАЛЬНОЇ ФІНАНСОВОЇ НЕСТАБІЛЬНОСТІ
}

У статті проаналізовано заходи антикризової політики Польщі та Німеччини в умовах фінансово-економічної кризи 2008-2009 рр. Визначено джерела фінансування економіки Украйни в умовах фінансової нестабільності. Проаналізовано програхи фінансової підтримки МВФ для України у 2008-2018 рр. Визначено ключові напрями забезпечення стійкості економіки та заходи їх реалізаиї.

Ключові слова: стійкість економіки, шокові впливи, фінансово-економічна криза, фінансова нестабільність, глобальний економічний простір,інвестиизійний клімат, грошово-кредитна політика.

The financial instability of the world economic space and the accelerated changes in the structure of its socio-economic environment affect the development of national economies in conditions of shocks that cause economic losses, disrupt the parameters of the economic system and create the threat of financial and economic crises. In order to respond quickly to the emergence of shocks in the face of global financial instability, the article identifies key areas of resilience. On the example of anti-crisis policies of European countries such as Poland and Germany, it was determined that the key directions of ensuring the resilience of their economies were investment privileges and attractive credit conditions.

Poland's attractive investment climate has ensured a stable growth of its economy after the 2008-2009 crisis. The GDP per capita GDP growth rate in 2008-2017 was $37.48 \%$.The introduction of an attractive lending system in Germany has ensured a rapid post-crisis economic recovery. The GDP per capita growth rate of Germany in 2008-2017 was 25.01\%. For Ukraine, during the period of the financial and economic crisis of 2008-2009 and the crisis that began in 2014, credit was used to support financial stability. Against the backdrop of falling foreign exchange reserves, devaluation of the national currency, Ukraine was motivated to cooperate with the IMF. For the period from 2008 to 2018, Ukraine was allocated under the IMF lending programs - \$ 66 billion, but in fact, \$27 billion was transferred due to Ukraine's failure to fulfill its obligations. The GDP per capita growth rate of Ukraine in 2008-2017 was 3.12\%. IMF financial assistance is one of the key areas for resilience of economy, as it involves systemic socio-economic reforms. Effective implementation of reforms will ensure economic growth and return investors' interest in the Ukrainian economy.

Key words: resilience of economy, shock influences, financial and economic crisis, financial instability, global economic space, investment climate, monetary policy. 
Постановка проблеми. Глобальна фінансова нестабільність стала ключовим фактором розвитку світової економіки та політики. На відміну від криз минулого століття, коли порівняно короткострокові періоди турбулентності і спаду змінювалися на періоди стабільності та зростання, фінансова нестабільність у XXI ст. стала трендом для більшості країн світу.

Нестабільність економічних процесів, дія шокових впливів та швидкість поширення кризових явищ у глобальному економічному просторі зумовлюють необхідність дослідження проблематики стійкості національних економік. Світова фінансово-економічна криза 2008-2009 рр. призвела до найбільш серйозного економічного спаду в історії світової економіки. Проте, не всі країни однаково пережили економічний спад і процес посткризового відновлення. Цей диференційований досвід зумовлює важливі питання: чому деякі країни та регіони виявляються більш стійкими до економічних потрясінь, ніж інші, і що саме впливає на рівень стійкості національних економік.

Вивчення та дослідження концепції стійкості в економіці почалося на початку 2000-х рр. Зокрема у 1997 р. професор економіки Майкл Райх у роботі «Соціальна структура теорії накопичення: ретроспектива і перспектива» визначив стійкість як здатність економіки запобігати, протистояти та швидко відновлюватися від дії шокових впливів. У 2008 р. задля забезпечення кількісної оцінки стійкості їі було визначено як здатність економіки, яка пережила дію шокового впливу, повернутися до свого попереднього рівня або темпу зростання виробництва чи зайнятості.

Починаючи 32009 р. концепція стійкості передбачала не тільки здатність економіки, після дії шокового впливу, повернутися до попереднього рівня розвитку, а й можливість уникнути або витримати такий вплив взагалі. Тоді ж почали досліджувати роль політики у зміцненні стійкості, яка може пом'якшити дію шокових впливів та наслідлки від фінансово-економічних криз.

Нестабільність світового економічного простору та прискорені зміни структури їі соціально-економічного середовища впливають на розвиток національних економік в умовах шокових впливів, які викликають економічні втрати, порушують параметри економічної системи та створюють загрозу виникнення фінансово-економічних криз. Для оперативного реагування економіки на появу шокових впливів в умовах глобальної фінансової нестабільності варто визначити ключові напрями забезпечення іiі стійкості,що актуалізує тему дослідження.

Аналіз останніх досліджень $і$ публікацій. Проблему забезпечення стійкості економічних систем активно вивчають українські та іноземні дослідники, економісти-практики. Дослідженню умов та напрямів забезпечення стійкості економіки щодо негативних зовнішніх впливів присвячена публікація А. Бойко (2017). Науковець визначив та класифікував фактори забезпечення стійкості національної економіки, до яких відніс соціально-політичні та економічні фактори, природно-екологічні та соціальні фактори, які показують співвідношення таких взаємопов'язаних складових національної стійкості, як природа, людина, суспільство, економіка, 
держава. Звідси забезпечення стійкості національної економіки здійснюється у межах ринкового саморегулювання, державного та суспільного регулювання, природної саморегуляції і саморозвитку [1].

Дослідженню економічної політики держави в умовах глобалізації присвячена публікація Ю. Уманціва (2017). Автор проаналізував глобальні тенденції формування і розвитку економічної політики держави, визначив напрями використання в Україні світового досвіду реалізації економічної політики, а саме: перебудова грошово-кредитної та бюджетно-податкової політики; модернізація фінансових ринків зі спрямуванням на вирішення макроекономічних завдань реконструктивного розвитку; перебудова аграрної сфери; модернізація виробничої інфраструктури; підвищення якості соціальних стандартів і соціального забезпечення [2].

Дослідженню теоретико-методологічних аспектів визначення впливу стабільності та шокових впливів на розвиток економіки присвячена монографія І. Крючкової (2010). Авторка зазначає, що глобальна економіка дедалі більше входить у зону невизначеності і перебуває під прискореним впливом кліматичних, технологічних, політичних, культурних та економічних змін, які підривають стабільність розвитку і постійно несуть у собі ті чи інші збурення та потенційні ризики. Причому, як це демонструе глобальна фінансово-економічна криза, дестабілізація однієї складової світового господарства негативно впливає на інші їі складові, а одночасний дисбаланс кількох важливих компонентів може підштовхнути до потужних руйнівних наслідків за умови низької адаптивності економіки [3].

Дослідженню стійкості соціально-економічних систем до економічних шокових впливів присвячена публікація Ю. Брунекієне (2019). Дослідник зазначає, що вплив економічних шоків на розвиток соціально-економічної системи може бути двостороннім: або негативним (може завдати шкоди економіці), або позитивним (економічні потрясіння можуть дати нові можливості для розвитку соціально-економічної системи) [4]. Отже, шокові впливи можуть прямо чи опосередковано впливати як на суб'єктів соціально-економічної системи, так і на всю економіку.

Дослідженням напрямів забезпечення стійкості економіки займається Европейська Комісія (2017). До ключових таких напрямів вона відносить: підтримку рівня зайнятості; забезпечення фінансової стабільності; підтримку регіональної політики з метою зниження диспропорцій у розвитку депресивних регіонів; фінансову допомогу країнам, що зазнають труднощів з бюджетним фінансуванням [5].

Метою статmі є визначення напрямів забезпечення стійкості національної економіки в умовах глобальної фінансової нестабільності. Для досягнення мети вирішено такі завдання:

1. Проаналізовано антикризові заходи забезпечення розвитку Польщі та Німеччини в умовах фінансово-економічної кризи 2008-2009 рр.

2. Визначено джерела фінансування української економіки в умовах фінансової нестабільності.

3. Запропоновано заходи реалізації ключових напрямів забезпечення стійкості економіки. 
Теоретико-методологічною основою дослідження є загальнонаукові та спеціальні методи наукового пізнання, зокрема аналізу, синтезу, порівняння та систематизації, застосування яких дало змогу досягти поставленої мети.

Результати дослідження. Сучасний стан і тенденції розвитку світової фінансової системи свідчать, що сьогодні посилюються ризики перманентного зародження та розгортання в «ії просторі» кризових явищ [6, с. 25]. Забезпечення стійкості економіки в умовах глобальної фінансової нестабільності є однією з найбільш актуальних проблем, що стоять перед більшістю країн світу. Ціллю забезпечення стійкості є захист економіки, іï секторів та галузей від негативних шокових впливів. Питання очікуваності чи неочікуваності появи шокових впливів, довкола якого науковці не дійшли остаточної думки, залишається дискусійним. Зважаючи на циклічність розвитку економіки, що зумовлюе певну закономірність виникнення шокових збурень, а також наявність суттєвих розбіжностей рівня внутрішніх та світових цін, деякі шокові зміни умов господарювання можуть бути передбачуваними та очікуваними і водночас справдяти реадьний ефект на розвиток економіки. Таким чином, шокові впливи можна визначити як реальну раптову зміну в умовах господарювання, що виводять параметри економічної системи за критичні (порогові) значення [3, с. 5].

Ключова роль, яку державні органи влади виконують після дії шокових впливів на економіку, - це стабілізація ситуації за рахунок визначених заходів та ресурсів. Другий вимір державної політики полягає у сприянні економічному відродженню, допомозі секторам і галузям економіки адаптуватися до нових обставин. Здатність мобілізувати фінанси та ресурси на національному рівні є ключовою умовою швидкого відновлення економіки після дії шокових впливів.

Варто зазначити, що стійкість економіки визначається іiі здатністю уникнути або витримати шоковий вплив і швидко відновитися, збільшуючи валовий внутрішній продукт (ВВП) на потенційний докризовий рівень [7]. Не існуе єдиної чітко визначеної системи побудови стійкості економіки, проте досвід іноземних країн дозволяе визначити спільні напрями іiі забезпечення. На прикладі антикризової політики таких європейських країн, як Польща та Німеччина, було визначено основні напрями забезпечення стійкості економіки. Вибір саме цих двох країн був зроблений 3 таких міркувань:

- Польща є стратегічним партнером України і займає важливе місце у транскордонному співробітництві. Польська економіка - один із лідерів у СС за темпами зростання ВВП. До 2008 р. середні темпи зростання української та польської економік були дуже близькими. Однак після 2009 р. розрив у їхньому розвитку постійно збільшується. Темп приросту ВВП на душу населення Польщі за 2008-2017 рр. становив 37,48 \%.

- Німеччину було вибрано як країну-члена EC із найвищими значеннями показників економічного розвитку (входить до 10 країн Европи 3 найбільшим розміром ВВП). Темп приросту ВВП на душу населення Німеччини за 2008-2017 рр. становив 25,01\%. 
У таблиці 1 наведено динаміку рівня ВВП на душу населення Польщі, Німеччини та України у 2008-2017 рр.

Таблицяя 1

Динаміка рівня ВВП на душу населення за ПКС Польщі, Німеччини та України (дол. США) [8]

\begin{tabular}{|c|c|c|c|}
\hline Роки & Польща & Німеччина & Україна \\
\hline 2008 & $\mathbf{1 8 3 1 0 , 4 4}$ & $\mathbf{3 8 ~ 0 2 8 , 7 7}$ & $\mathbf{8 3 9 5 , 8 1}$ \\
\hline 2009 & 19242,99 & 37035,78 & 7239,62 \\
\hline 2010 & 21068,85 & 39225,60 & 7666,22 \\
\hline 2011 & 22850,64 & 42692,52 & 8281,87 \\
\hline 2012 & 23833,21 & 43564,15 & 8475,47 \\
\hline 2013 & 24719,25 & 45232,20 & 8629,68 \\
\hline 2014 & 25602,42 & 47092,49 & 8684,01 \\
\hline 2015 & 26594,76 & 47810,84 & $\mathbf{7 9 4 9 , 1 5}$ \\
\hline 2016 & 27383,25 & 48943,10 & 8269,61 \\
\hline 2017 & 29291,35 & 50715,55 & 8666,90 \\
\hline Приріст за 10 років, \% & $37,48 \%$ & $25,01 \%$ & $3,12 \%$ \\
\hline
\end{tabular}

У таблиці 1 жирним шрифтом виділено значення рівня ВВП на душу населення у кризовий період часу (2008 р. - для всіх країн; 2015 р. - для України) і значення цього показника у відповідних періодах, коли він досяг докризового рівня (2008 р.).

Польща є однією 3 небагатьох країн, якій вдалося стабільно зростати після кризи 2008-2009 рр. Одним з основних факторів, що ефективно захистив Польщу від наслідків світової кризи, був привабливий інвестиційний клімат.Польський уряд створив бездіч інвестиційних стимулів для іноземних компаній. Одним з них є можливість розміщення інвестицій у Вільній економічній зоні (ВЕ3), що передбачає ведення господарської діядьності на спеціальних пільгових умовах. ВЕЗ пропонує новим інвесторам податкові пільги, сприяння в працевлаштуванні і підготовлення території для здійснення інвестицій.

У Польщі також існує розвинена система виділення урядових грантів у рамках Програми підтримки інвестицій, що мають важливе значення для економіки країни. Підтримка надається у формі дотації на підставі двостороннього договору між міністром економіки й інвесторами. Договір детально регулює виплату дотації і виплачується пропорційно до реалізації взятих на себе інвестором зобов'язань.

На отримання інвестицій можуть розраховувати підприємства, які планують інвестиції у таких пріоритетних секторах, як: машинобудування, побутове приладобудування, авіаційна промисловість, біотехнології, виробництво продуктів харчування, послуги 3 розвитку сучасних технологій, дослідження і розвиток (Research And Development - R \& D). Привабливість Польщі для інвесторів базується на таких ключових чинниках: 
1. Макроекономічна стабільність. Стабільний фінансовий розвиток дає можливість для довгострокового планування інвестицій. Польща була єдиною країною в Европі, яка уникла економічного спаду під час фінансово-економічної кризи.

2. Інфраструктурні інвестиції. Сильний стимул розвитку Польщі надають великі інвестиції в інфраструктуру країни з фондів Евросоюзу та інших країн: будівництво автомобільних доріг, залізничних колій, нових аеропортів, об'єктів промисловості та енергетики.

3. Різновекторність розвитку економіки. Польський уряд приділяе значну увагу розвитку різних галузей економіки, що дозволяе країні розвиватися у всіх напрямах і не потрапляти в сильну залежність від кон'юнктури галузевих ринків.

4. Високий рівень якості товарів та послуг. Еластичність підприемств і висока конкуренція дозволяє підтримувати якість товарів та послуг на високому рівні.

Отже, як показала світова фінансово-економічна криза, Польща виявилася підготовленою до протидії шоковим впливам завдяки привабливому інвестиційному клімату. Далі розглянемо досвід Німеччини, якій вдалося успішно подолати шокові впливи завдяки поєднанню пакетів економічних стимулів та гнучкої грошово-кредитної політики (запровадження низьких процентних ставок на кредити).

У кінці 2008 р. палата німецького парламенту схвалила пакет економічних стимулів (заходів) на суму 39,12 млрд. дол., спрямований на підтримку найбільшої в Европі економіки під час світової рецесії. Пакет заходів передбачав підтримку будівельних проектів, кредитування компаній, інвестиції в комунадьне господарство, скорочення податків та іншу економічну допомогу.

3 метою забезпечення кредитування підприємств малого та середнього бізнесу, підтримки їх фінансування в умовах дефіциту банківської системи в Німеччині були зміцнені кредитні можливості приватних банків за рахунок їх додаткового фінансування Банком реконструкції на суму 15 млрд. євро. Право на отримання кредиту в рамках цієї програми мали всі підприємства, незалежно від галузі, річний оборот яких становив не більше 500 млн. євро. Ініціатива отримала назву «Спеціальна програма Банку реконструкції з підтримки підприємств малого і середнього бізнесу». Особливостями зазначеної схеми кредитування були:

- сума одного кредиту - до 50 мдн. євро на кожний конкретний проєкт;

- можливість звернення за додатковим кредитом у разі розробки організацією нового проєкту;

- у рамках заходу не передбачалося фінансування організацій, які потребують підтримки на середню і довгострокову перспективу (наприклад суднобудування) [9].

Паралельно для компаній з оборотом понад 500 млн. євро на рік було запущено аналогічну «Спеціальну програму Банку реконструкції 3 підтримки підприємств великого бізнесу» на суму в 25 млрд. євро. Крім того, федеральний уряд ініціював продовження програми кредитних гарантій 
для німецьких підприємств і надав їм додатково 75 млрд. євро у вигдяді поручительств і гарантій.

Політика дешевих кредитів, яка проводилася у німецькому банківському секторі після фінансово-економічної кризи, стимулювала зростання іпотечного попиту та інвестиційної активності в економіці. Банківські установи, надаючи низькопроцентні кредити реальному сектору економіки за вигідними умовами, забезпечили зростання виробництва товарів і послуг та дали поштовх до економічного зростання. Варто зазначити, що політика дешевих кредитів активно проводиться в Німеччині і досі.

Згідно зі статистикою Бундесбанку, з червня по грудень 2015 р. середня ставка за споживчими кредитами на термін від 1 до 5 років становила 4,78\% річних, за кредитами на строк від 5 років - 7, 19\%. При цьому ставки по десятирічних іпотечних кредитах на початок лютого 2016 р. становили 1,4\% річних. 3 кінця 2017 р. деякі банки пропонували німцям споживчі кредити під 0\% річних, що було пов'язано з бажанням привернути увагу і задовольнити клієнтський попит.

У 2018 р. найвигідніша відсоткова ставка, під яку можна було взяти споживчий кредит у Німеччині, дорівнювала 2,5%. Мінімадьна сума позики при цьому становила від 3 до 5 тис. євро залежно від банку. За кредитами понад 10 тис. євро строком на 3 роки ставки на ринку дещо різнилися. Найдорожчі позики, під 7,99 \% річних, видавав Deutsche Bank. У Боннського Norisbank ставка становила 4,9 \% річних, у ComdirectBank - 4,75 \% [10].

В Україні, для порівняння, середньозважені ставки по гривневих кредитах для фізичних осіб обчислюються двозначними числами. У 2018 р. згідно з даними НБУ споживчі кредити терміном до 1 року видавадися під 30,6 \% річних, на період від 1 до 5 років - під 33,5 \% річних, на період більше 5 років - під 19,8 \%. Для фізичних осіб-підприємців середньозважена процентна ставка за новими кредитами у 2018 р. становила 24,2\% [11]. Високі кредитні ставки є загрозою для розвитку української економіки, оскільки підприємства не хочуть брати дорогі кредити. А це означає, що вони не розвивають нові проєкти, які могли б розвивати за наявності доступних позик. Відтак економіка не отримує стимулу для зростання.

Для України у період фінансово-економічої кризи 2008-2009 рр. та кризових явищ, які розпочалися у 2014 р., для підтримки фінансової стабільності необхідним було надходження іноземної валюти в країну за статтею «прямі іноземні інвестиції» або за статтею «кредитний ресурс». Що стосується прямих іноземних інвестицій, то їх приплив є похідним від якості бізнес-клімату в країні. Реформи в Україні проводилися повільно та частково, а це означає, що якість бізнес-клімату не поліпшувалась і приплив прямих іноземних інвестицій не зростав.

Тож єдиною можливістю забезпечення припливу інвестицій був кредитний ресурс. На тлі зниження золотовалютних резервів, девальвації національної валюти Україна була мотивована на співпрацю з Міжнародним валютним фондом (МВФ). За період з 2008 по 2018 р. Україні було виділено за програмами кредитування МВФ - 66 млрд. дол., проте фактично було перераховано 27 млрд. дол. через невиконання Україною 
своїх зобов' язань. Темп приросту ВВП на душу населення України за 20082017 рр. становив 3,12 \%.

Характеристику програм фінансової підтримки МВФ для України у 2008-2018 роках наведено у таблиці 2.

Таблиция 2

\section{Програми фінансової підтримки МВФ для України у 2008-2018 роках [12]}

\begin{tabular}{|c|c|c|}
\hline № & Рік, місяць & 2008 р. листопад. \\
\hline \multirow{4}{*}{1.} & Сума кредиту & 16,4 млрд. дол. на 15 років під 4\% річних. \\
\hline & $\begin{array}{l}\text { Фактично от- } \\
\text { римано }\end{array}$ & 10,6 млрд. дол. за2008-2009 рр. \\
\hline & Вимоги & $\begin{array}{l}\text { Кредит спрямовувався на відновлення макроекономічної та } \\
\text { фінансової стабільності України: планувалось, що інфляція } \\
\text { знизиться до 17\% до кінця } 2009 \text { р.; забезпечення «помірного» } \\
\text { дефіциту бюджету до } 2010 \text { р.; сповільнення падіння ВВП до } \\
\text { 2\% у рік; введення гнучкого валютного курсу; виведення } 3 \\
\text { ринку проблемних банків і рекапіталізація життєздатних. }\end{array}$ \\
\hline & $\begin{array}{l}\text { Ступінь вико- } \\
\text { нання вимог }\end{array}$ & $\begin{array}{l}\text { Бюджет України у } 2009 \text { р. був дефіцитним, що суперечило } \\
\text { умовам видачі кредиту. Виплати МВФ було припинено. }\end{array}$ \\
\hline \multirow{5}{*}{2.} & Рік, місяць & 2010 р. липень. \\
\hline & Сума кредиту & 15,15 млрд. дол. на 2,5 роки. \\
\hline & $\begin{array}{l}\text { Фактично от- } \\
\text { римано }\end{array}$ & 3,39 млрд. дол. за2010-2013 рр. \\
\hline & Вимоги & $\begin{array}{l}\text { Забезпечення консолідації державних фінансів, відновлен- } \\
\text { ня стійкості банківської системи та розробка більш міцної } \\
\text { основи грошово-кредитної політики. Україна зобов'язува- } \\
\text { лась провести реформи з модернізації газового сектора та } \\
\text { усунути дефіцит Нафтогазу починаючи з } 2011 \text { року, в тому } \\
\text { числі за рахунок підвищення тарифів на газ. }\end{array}$ \\
\hline & $\begin{array}{l}\text { Ступінь вико- } \\
\text { нання вимог }\end{array}$ & $\begin{array}{l}\text { Уряд не виконував умови програми співпраці: не вирішив } \\
\text { проблему з дефіцитом бюджету, не підвищив ціни на енер- } \\
\text { гоносії, не займався рекапіталізацією банків. Виплати МВФ } \\
\text { було припинено. }\end{array}$ \\
\hline \multirow{5}{*}{3.} & Рік, місяць & 2014 р. квітень. \\
\hline & Сума кредиту & 17,01 млрд. дол. на 2 роки. \\
\hline & $\begin{array}{l}\text { Фактично от- } \\
\text { римано }\end{array}$ & 4,3 млрд. дол. за2014-2015 рр. \\
\hline & Вимоги & $\begin{array}{l}\text { Забезпечення оздоровлення банківської системи, проведен- } \\
\text { ня реформ у газовій сфері, скорочення бюджетних витрат, } \\
\text { ефективна боротьба з корупцією і поліпшення ділового кді- } \\
\text { мату та прозорості ведення бізнесу. }\end{array}$ \\
\hline & $\begin{array}{l}\text { Ступінь вико- } \\
\text { нання вимог }\end{array}$ & $\begin{array}{l}\text { Більша частина коштів була перерахована на покриття де- } \\
\text { фіциту держбюджету. Виплати МВФ було припинено. }\end{array}$ \\
\hline
\end{tabular}




\begin{tabular}{|c|c|c|}
\hline \multirow{5}{*}{4.} & Рік, місяць & 2015 р. березень. \\
\hline & Сума кредиту & 17,516 млрд. дол. на 4 роки. \\
\hline & $\begin{array}{l}\text { Фактично от- } \\
\text { римано }\end{array}$ & 8,7 млрд. дол. за2015-2018 рр. \\
\hline & Вимоги & $\begin{array}{l}\text { Забезпечити виведення з банківського сектору неплатоспро- } \\
\text { можних банків; націонадізувати «Приватбанк»; легалізува- } \\
\text { ти видобуток бурштину та азартні ігри; підвищити тарифи } \\
\text { на газ; провести пенсійну реформу; продовжити боротьбу } \\
\text { корупцією; скасувати мораторій на продаж землі. }\end{array}$ \\
\hline & $\begin{array}{l}\text { Ступінь вико- } \\
\text { нання вимог }\end{array}$ & $\begin{array}{l}3 \text { грудня } 2018 \text { р. кредитну програму замінили на програму } \\
\text { stand-by. }\end{array}$ \\
\hline
\end{tabular}

Деякі вимоги МВФ негативно сприймаються в українському суспільстві, наприклад зростання тарифів на комунальні послуги. Якщо не підвищувати тарифи на газ і не отримувати гроші від $М В Ф$, це може призвести до скорочення державних витрат, що негативно позначиться на публічних інвестиціях, зниженні рівня заробітної плати і пенсій, стане причиною рецесіі. Також у цьому разі є мождивим варіант дефолту, який призведе до схожих і навіть гірших наслідків: девальвація гривні, високий рівень інфляції, зниження купівельної спроможності. Варто зазначити, що девальвація призведе до значного збільшення кількості громадян з низьким рівнем доходу, у яких немає накопичень в іноземній валюті або в інших безпечних активах.

Інша проблема полягає в тому, що дефолт, девальвація і рецесія ще більше підвищать неминуче зростання тарифів на газ у майбутньому, але без зростання економіки та рівня заробітної плати. Підвищення тарифів на газ зараз також матиме прямі негативні наслідки на реальну купівельну спроможність та рівень інфляції, але тільки тимчасово. Ці витрати будуть непорівнянні з витратами та наслідками дефолту або скорочення державних витрат. Крім того, негативні наслідки від зростання тарифів для громадян з низьким рівнем доходу будуть компенсовані субсидіями.

Варто зазначити, що однією з кдючових вимог МВФ до України є реалізація ефективних заходів боротьби з корупцією. МВФ вважає, що прояви корупції у всіх секторах та галузях економіки не дають країні мождивості економічно зростати та ефективно розвиватись. Завдяки антикорупційним вимогам МВФ, Україні за короткий час вдалося створити систему антикорупційних органів та прийняти низку законів. Проте проблема неефективності діяльності антикорупційних органів задишається невирішеною.

Отже, фінансова допомога МВФ є кдючовим напрямом забезпечення стійкості економіки, оскільки передбачає проведення системних соціально-економічних реформ. Ефективне впровадження реформ забезпечить економічне зростання та поверне інтерес інвесторів до української економіки.

Висновки. Досвід України та європейських країн у забезпеченні розвитку економіки в період фінансово-економічної кризи дозволяе визначити кдючові напрями забезпечення стійкості економіки та заходи їх реалізації: 
1. Інвестиційні пільги: виділення урядових грантів у рамках програми підтримки інвестиційної діяльності; звільнення від оподаткування дивідендів зі стратегічних інвестицій, які спрямовані на створення нових підприємств і виробництв; впровадження пільгового кредитування як захід підтримки та стимулювання інвесторів.

2. Привабливі умови кредитування: зниження кредитних ставок для малого та середнього бізнесу; забезпечення розвитку системи довгострокового кредитування в галузях економіки, що експортують національну промислову продукцію; зниження ставок за іпотечним кредитом для населення.

3. Міжнародна фінансова підтримка: забезпечити виконання всіх вимог та умов програми фінансової підтримки.

Зазначені заходи спрямовані на реалізацію державної підтримки розвитку ключових напрямів забезпечення стійкості національної економіки. Ефект від цих заходів в умовах глобальної фінансової нестабільності забезпечить приплив прямих іноземних інвестицій у реальний сектор економіки, зростання рівня виробництва та зайнятості, збалансування державного бюджету, зростання довіри інвесторів та світової спільноти.

Перспективи подальших досліджень у цьому напрямі пов' язані з обгрунтуванням фінансово-економічних інструментів забезпечення стійкості секторів економіки.

\section{СПИСОК ВИКОРИСТАНИХ ДЖЕРЕ $Д$}

1. Бойко А.В. Забезпечення стійкості національної економіки // Зовнішня торгівля: економіка, фінанси, право. - 2017. - № 4 (93). - C. 16-27.URL: http://zt.knteu.kiev. ua/files/2017/04(93)/02.pdf

2. Уманців Ю.М. Економічна політика держави в умовах глобалізації // Вісник Київського національного торговельно-економічного університету. - 2017. - № 1 (111). - C. 5-18. URL:http://visnik.knteu. kiev.ua/files/2017/01/2.pdf

3. Крючкова І.В. Економіка України: шокові впливи та шлях до стабільного розвитку: монографія. - Київ: Інститут економіки та прогнозування НАН України, 2010. - 480 с.

4. Bruneckiene J. An Assessment of Socio-Economic Systems' Resilience to Economic Shocks: The Case of Lithuanian Regions// Sustainability. - 2019. - № 11. - P. 1-24. URL: https://ideas.repec.org/a/gam/jsusta/v11y2019i3p566-d199849.html

5. Economic resilience in EMU. European Commission. Directorate general economic and financial affairs. -Brussels, 2017. -13 p. URL:https://www.consilium.europa.eu/media/23535/eurogroup-15-september-item1-com-note-economic-resilience-in-emu.pdf

6. Черленяк I.I. Міжнародний офшорний бізнес та глобальна фінансова система // Проблеми економіки. - 2014. - № 2. - C. 24-29. URL: http://www.problecon.com/ export_pdf/problems-of-economy-2014-2_0-pages-24_29.pdf

7. Annual Growth Survey 2018. European Commission. - Brussels, 2017. -15 p. URL:https://ec.europa.eu/info/sites/info/files/2017-comm-690_en_0.pdf

8. GDP percapita, PPP (current international \$).The World Bank. - 2017. URL: http:// data.worldbank.org/

9. Goerres A. The Political Consequences of National Crisis Management: Micro-Level Evidence from German Votersduringthe 2008/09 Global Economic Crisis// German 
Politics. - 2016. - № 25. - P. 131-153. URL: https://www.tandfonline.com/doi/abs/10.1 080/09644008.2015.1134495

10. Borio C. Monetary policy and bank lending in a low interest rate environment: diminishing effectiveness?// Bank for International Settlements. - 2017. - № 612. - C. 1-33. URL: https://www.bis.org/publ/work612.pdf

11. Основні показники діяльності банків України. Показники банківської системи. Статистика. Національний Банк України. URL: https://bank.gov.ua/

12. Зануда А. МВФ і Україна: історія позик і відносин // ВВС News Україна. - 2019. URL: https://www.bbc.com/ukrainian/features-48335639

\section{REFERENCES}

1. Boiko, A.V. (2017). Zabezpechennya stiykosti natsional'noyi ekonomiky [Ensuring the resilience of the national economy]. Zovnishnyatorhivlya: ekonomika, finansy, pravo-ForeignTrade: Economics, Finance, Law, 4 (93), 16-27. Retrieved from http://zt.knteu. kiev.ua/files/2017/04(93)/02.pdf [in Ukrainian].

2. Umantsiv, YU.M. (2017). Ekonomichna polityka derzhavy v umovakh hlobalizatsiyi [State economic policy in globalization]. Visnyk Kyyivs'koho natsional'noho torhovel'no-ekonomichnoho universytetu - Herald of Kyiv National University of Trade and Economics, 1 (111), 5-18. Retrieved from http://visnik.knteu. kiev.ua/files/2017/01/2.pdf [in Ukrainian].

3. Kryuchkova, I.V. (2010). Ekonomika Ukrayiny: shokovi vplyvy ta shlyakh do stabil'noho rozvytku [Ukraine's economy: shocks and the path to sustainable development]. Kyiv, 480 [in Ukrainian].

4. Bruneckiene, J. (2019). An Assessment of Socio-Economic Systems' Resilience to Economic Shocks: The Case of Lithuanian Regions. Sustainability. No 11, 1-24. Retrieved from https://ideas.repec.org/a/gam/jsusta/v11y2019i3p566-d199849.html [in English].

5. Economic resilience in EMU (2017). European Commission. Directorate general economic and financial affairs. Brussels,13. Retrieved from https://www.consilium.europa.eu/media/23535/eurogroup-15-september-item1-com-note-economic-resiliencein-emu.pdf[in English].

6. Cherlenyak, I.I. (2014). Mizhnarodnyy ofshornyy biznes ta hlobal'na finansova systema [International offshore business and the global financial system]. Problemy ekonomiky - Problems of Economy, 2, 24-29. Retrieved from http://www.problecon.com/export_pdf/problems-of-economy-2014-2_0-pages-24_29.pdf [in Ukrainian].

7. European Commission (2017). Annual Growth Survey 2018. Brussels, 15. Retrieved from https://ec.europa.eu/info/sites/info/files/2017-comm-690_en_0.pdf [in English].

8. GDP percapita, PPP (current international \$).TheWorldBank.2017. Retrieved from http://data.worldbank.org/ [in English].

9. Goerres, A. (2016). The Political Consequences of National Crisis Management: Micro-Level Evidence from German Voters during the 2008/09 Global Economic Crisis. German Politics, 25, 131-153. Retrieved from https://www.tandfonline.com/doi/ abs/10.1080/09644008. 2015.1134495 [in English].

10. Borio, C. (2017). Monetary policy and bank lending in a low interest rate environment: diminishing effectiveness? Bank for International Settlements, 612, 1-33. Retrieved from https://www.bis.org/ publ/work612.pdf [in English].

11. Osnovni pokaznyky diyal'nosti bankiv Ukrayiny. Pokaznyky bankivs'koyi systemy. Statystyka [Basic indicators of activity of banks of Ukraine. Banking system indicators. Statistics]. bank.gov.ua. Retrieved from https://bank.gov.ua/[in Ukrainian].

12. Zanuda, A.(2019). MVF i Ukrayina: istoriya pozyk i vidnosyn [IMF's bore and Ukraine: history of loans and relations]. BBS News Ukrayina - BBC News Ukraine. Retrieved from https://www.bbc.com/ukrainian/features-48335639 [in Ukrainian]. 